\title{
Post-diagnosis abortion in women living with HIV/Aids in the south of Brazil
}

Flávia Bulegon Pilecco ${ }^{1}$

Luciana Barcellos Teixeira ${ }^{2}$

Álvaro Vigo ${ }^{1}$

Daniela Riva Knauth ${ }^{1}$

\footnotetext{
${ }^{1}$ Programa de PósGraduação em Epidemiologia, Universidade Federal do Rio Grande do Sul (UFRGS). Porto Alegre RS Brasil. flaviapilecco@yahoo.com.br ${ }^{2}$ Departamento de Assistência e Orientação Profissional, Escola de Enfermagem, UFRGS.
}

\begin{abstract}
Objective: To understand how the HIV diagnosis combines with other factors that influence the decision to abort. Methodology: Data were collected during a crossover study of women aged between 18 and 49 years old and seen in public health services in Porto Alegre, Brazil. The life stories of 18 interviewees who had post-diagnosis abortion were reconstructed on a timeline, using information collected quantitatively. Results: The time between the diagnosis and abortion was 2 years or less for more than half of the women. For some, post-diagnosis abortion did not mean the end of reproductive life. The most frequent reason for terminating pregnancy was to be living with HIV; however, only some of the women who stated having this motivation did not have post-diagnosis children. Changing partners between pregnancies was a recurring finding; however, in most pregnancies that ended in abortion, the women lived with their partners. Discussion: The analysis of the reproductive trajectory of the women studied showed that there is no specific profile of the woman who aborts after receiving the HIV diagnosis. Although this diagnosis may be involved in the decision to terminate a pregnancy, it does not necessarily result in the end of a woman's reproductive trajectory. Thus, abortion should be understood within a diversity of decision-making processes and the specific moment of a woman's life story.
\end{abstract}

Key words Abortion, HIV, Reproductive health 


\section{Introduction}

Advancements in HIV/Aids prevention and treatment have enabled women living with HIV/ Aids (WLHA) to take a pregnancy to term with low risk of transmitting the virus to the fetus'. Chances of infecting the child may reach $45 \%$ in the absence of antiretroviral drugs use. However, these chances may be reduced to nearly zero if the protocol to prevent vertical transmission is followed thoroughly ${ }^{2}$.

The success of this protocol in the reduction of infections transmitted from mother-to-child is the result of medications available and HIV tracking policies, as well as prenatal follow-up. However, this investment does not contemplate one of the sides of reproductive rights, which is not having children, or having them at intervals considered adequate by the woman and/or the couple. Thus, women not adapted to using a condom as a contraceptive method and who do not want children or, still, who want to interrupt a pregnancy end up in second place in health care services, whose priority are pregnant women. Often, these women do not find in health services more adequate alternatives to manage their reproductive life ${ }^{3}$. Moreover, from the standpoint of reproduction, women's viewpoint also has implications in the late diagnosis of women who do not have children or who are out of the reproductive age group 4 .

When taking reproductive decisions, the WLHA take into consideration the fact they live with HIV and the possible risk of transmission of the virus to the fetus. Furthermore, they are subject to individual factors, social aspects, and cultural expectations $s^{5}$. The literature on post-diagnosis abortion in WLHA is quite limited ${ }^{6}$, but it indicates that the risk of transmission of the virus to the fetus was one of the factors that weighed on reproductive decisions. The introduction of the Protocol for Prevention of Mother-to-Child Transmission (PMTCT) has produced a decrease in the rate of pregnancies ended in induced abortion $^{7-10}$. Nevertheless, these rates remain high: $17.5 \%$ in Brazil $^{11}, 37.1 \%$ in Canada ${ }^{10}, 47 \%$ in Australia ${ }^{12}, 53 \%$ in 12 European countries ${ }^{7}$, $62.9 \%$ in a cohort conducted in France ${ }^{8}$ and $68 \%$ in Vietnam9. On the other hand, some studies suggest that living with the virus is not the only reason why these women decide to abort; there is also an association between induced abortion post-diagnosis and socioeconomic characteristics. In this manner, qualitative studies conducted in Brazil, Vietnam and Cape Town indicate as reasons for induced abortion fear of losing one's job $^{3}$ and fear of not having the financial means to raise a child ${ }^{9,13,14}$.

The history of reproductive decisions is also reflected in the continuation or interruption of a post-diagnosis pregnancy. Thus, studies conducted in Italy ${ }^{15}$ and France ${ }^{8}$ indicate that a pregnancy is more likely to end in abortion if the woman has already had previous pregnancies. Moreover, some studies show that lack of pregnancy planning is associated to abortion ${ }^{15}$ and that not wanting to become a mother in that moment of life is one of the reasons that lead women to abort ${ }^{3}$.

However, a review of the literature on abortion by WLHA does not allow one to understand how these different factors influence in the decision to interrupt a pregnancy post-diagnosis, especially in countries where abortion is illegal ${ }^{6}$. For instance, the role played by HIV in these decisions and the weight they gain throughout the life of WLHA are unclear.

Thus, the present paper aims to understand how the HIV diagnosis relates to other factors that compete for the decision to abort, particularly in the context of illegality of induced abortion, seeking to analyze abortion post-diagnosis of HIV within the specific context of post-diagnosis pregnancy and the woman's reproductive life.

\section{Methodology}

The present paper analyzes the data collected from an observational study: "Reproductive and Sexual Health of Women Living in the Context of the HIV/Aids Epidemics in Porto Alegre, Brazil". The study was conducted in public health services in the city of Porto Alegre, Brazil and was financed by the National Council for Scientific and Technological Development (CNPq in its Portuguese abbreviation).

The study population was comprised of women aged between 18 and 49 years old who sought the public services of the city. The women were divided into the following two groups: WLHA and women not living with HIV/Aids (WNLHA). The WLHA were recruited in all specialized services that have a specific agenda to care for people living with HIV/Aids in Porto Alegre. The WNLHA came from primary health care services in Porto Alegre. These primary health care services were randomly selected and encompassed all sanitary districts of the city. The 
number of women recruited in each service was proportional to the number of appointments given, and interviewees were randomly selected from the appointment books of these services.

The sample size was calculated based on the study by Barbosa et al. ${ }^{11}$, which estimated the prevalence of induced abortion for the two populations studied (WLHA and WNLHA). Considering a power of $80 \%$, a level of significance of $5 \%$, a design effect (deff) of 1.6, and increasing the sample by $20 \%$ for possible losses, the sample size was estimated at 615 WLHA and $615 \mathrm{WN}$ LHA. Of the WLHA, 65 refused to participate in the study and of the WNLHA, 41 were in the same situation. As a result, the final sample was composed of 684 WLHA and 639 WNLHA. Of the WLHA, 126 had pregnancies that resulted in induced abortion and 18 reported having aborted after receiving the diagnosis of HIV infection.

Data was collected between January and November 2011. The data collection tool was a questionnaire given by an interviewer. The questions were objectives and addressed socioeconomic and demographic characteristics and sexual and reproductive health, such as affective-sexual relationships, contraception, condom use, pregnancies, abortion, the HIV diagnosis and violence (physical, psychological, and sexual).

As the objective of the present study was to make an in-depth analysis of abortions done due to the knowledge of being HIV positive, the data presented herein refer to 18 interviewees, who totaled 23 cases of post-diagnosis abortion (the number of women and the number of abortions differ because one woman had two abortions, and two women had three post-diagnosis abortions). Due to the small number of cases and the social and political relevance of understanding this phenomenon, it was decided that a descriptive and qualitative analysis of the conjugal, sexual, and reproductive trajectory of these women would be done. This analysis consisted of the reconstruction of the information quantitatively collected on a timeline in order to understand the contraceptive and reproductive trajectory of the women who had a voluntarily termination of a pregnancy after the HIV diagnosis and who informed the context of the pregnancy that was ended by induced abortion.

Thus, the following information was considered: socioeconomic and demographic information (age, race, religion, schooling, profession, income, and family support), information related to sexuality and reproduction (age at first sexual intercourse, use of contraception and use of condom in sexual initiation, number of partners during life, number of partners in the past 12 months, number of marriages, time since last sexual intercourse, use of contraception and condom in last intercourse, and number of children), specific information about the context of the pregnancy that resulted in abortion (number of children at the time of pregnancy, age at the time of pregnancy, history of abortions prior to that pregnancy, if the woman was using a contraceptive method when she got pregnant, if she lived with her partner at that time, if her partner was living with HIV and if the partner was the same as in the previous pregnancy), information to qualify abortion itself (gestational age at the time of abortion, where abortion was performed, if the woman needed post-abortion medical assistance, where she sought medical assistance, how this medical assistance was, whose initiative was it to abort and what the main reason to abort was), information on contexts that may expose the woman to greater social vulnerability (psychological, physical and sexual violence, drug use and paid sex), age when the woman found out to be HIV positive, why she took the test, and if she desired to have children in the future. Chart 1 shows a summary of the data as well as some variables about the WLHA who had a post-diagnosis abortion and the pregnancies that were voluntarily terminated.

This study was approved by the Ethics Committee of Universidade Federal do Rio Grande do Sul (the proposing research center) as well as by three other ethics committees responsible for the data collection centers. Interviewees could refuse or interrupt the questionnaire at any moment. Anonymity and confidentiality were ensured and all interviewees signed a Free and Informed Consent Term, as per resolution n. 196/96 ${ }^{16}$ of the National Research Ethics Council.

\section{Results}

Most (15) interviewees had only one pregnancy voluntarily terminated after the diagnosis. One woman reported two pregnancies terminated by abortion and two interviewees had three induced abortions after the diagnosis. Age at the pregnancy which resulted in abortion varied considerably; twelve women were aged less than 30 , four were aged between 30 and 39 , and two were aged 40 or older. As to race, five identified themselves as black, one as mixed race, and the remaining as white. As to schooling, most (10) had graduated 
Chart 1. Summary of life trajectory of women who had induced abortions after the HIV diagnosis.

\begin{tabular}{|c|c|c|c|c|c|c|c|c|c|}
\hline Name $^{a}$ & Age & \multicolumn{2}{|l|}{ Schooling } & $\begin{array}{c}\begin{array}{c}\text { Number } \\
\text { of } \\
\text { marriages }\end{array} \\
\end{array}$ & $\begin{array}{c}\text { Age at } \\
\text { diagnosis }\end{array}$ & \multicolumn{2}{|c|}{$\begin{array}{c}\text { Number of } \\
\text { children before } \\
\text { diagnosis }\end{array}$} & $\begin{array}{l}\text { Number of } \\
\text { children after } \\
\text { diagnosis }\end{array}$ & \begin{tabular}{|c} 
Age \\
at abortion
\end{tabular} \\
\hline Ana & 40 years-old & \multicolumn{2}{|c|}{ incomplete elementary school } & 3 & 30 & \multicolumn{2}{|c|}{3} & 0 & 30 \\
\hline Carla & 33 years-old & \multicolumn{2}{|c|}{ elementary school graduate } & 1 & 21 & \multicolumn{2}{|c|}{1} & 1 & 23 \\
\hline Maria & 32 years-old & \multicolumn{2}{|c|}{ incomplete elementary school } & 1 & 23 & \multicolumn{2}{|c|}{1} & 3 & 24 and 27 \\
\hline Alice & 39 years-old & \multicolumn{2}{|c|}{ incomplete elementary school } & 3 & 31 & \multicolumn{2}{|c|}{3} & 0 & 31 \\
\hline Camila & 42 years-old & \multicolumn{2}{|c|}{ incomplete elementary school } & 3 & 31 & \multicolumn{2}{|c|}{3} & 0 & 32 \\
\hline Aura & 36 years-old & \multicolumn{2}{|l|}{ high school graduate } & 2 & 18 & \multicolumn{2}{|c|}{1} & 0 & 23,28 and 35 \\
\hline Lorena & 48 years-old & \multicolumn{2}{|l|}{ college graduate } & 2 & 38 & \multicolumn{2}{|c|}{4} & 1 & 40 \\
\hline Tatiana & 31 years-old & \multicolumn{2}{|l|}{ high school graduate } & 2 & 19 & \multicolumn{2}{|c|}{1} & 0 & 20 \\
\hline Lúcia & 33 years-old & \multicolumn{2}{|l|}{ high school graduate } & 2 & 18 & \multicolumn{2}{|c|}{1} & 2 & 25 \\
\hline Name $^{a}$ & \multicolumn{2}{|c|}{ Partner at the time of abortion } & \multicolumn{4}{|c|}{ Reason for abortion } & \multicolumn{3}{|c|}{ Initiative for abortion } \\
\hline Ana & \multicolumn{2}{|c|}{ Same as in previous pregnancies } & \multicolumn{4}{|c|}{-} & \multicolumn{3}{|c|}{-} \\
\hline Carla & \multicolumn{2}{|c|}{ Same as in previous pregnancies } & \multicolumn{4}{|c|}{ Being HIV+ } & \multicolumn{3}{|c|}{ The woman's own } \\
\hline Maria & \multicolumn{2}{|c|}{$\begin{array}{l}\text { In neither of the two abortions it was } \\
\text { the same as in previous pregnancy }\end{array}$} & \multicolumn{4}{|c|}{$\begin{array}{l}\text { In both abortions the reason was the } \\
\text { woman being HIV+ }\end{array}$} & \multicolumn{3}{|c|}{$\begin{array}{l}\text { The first was the woman's and her } \\
\text { partner's relatives, and the last was } \\
\text { only hers }\end{array}$} \\
\hline Alice & \multicolumn{2}{|c|}{ Not the same as in previous pregnancy } & \multicolumn{4}{|c|}{ Lack of socioeconomic conditions } & The wo & man's own & \\
\hline Camila & Same as in pre & evious pregnancies & $\mathrm{Lac}$ & ck of socioecc & onomic con & ditions & The wo & man's own & \\
\hline Aura & $\begin{array}{l}\text { In neither of } t \\
\text { the same as in }\end{array}$ & $\begin{array}{l}\text { the three abortions it was } \\
\text { previous pregnancy }\end{array}$ & $\begin{array}{l}\text { For } \\
\text { the }\end{array}$ & $\begin{array}{l}\text { the first and } \\
\text { reason was } \mathrm{n} \\
\text { at th }\end{array}$ & $\begin{array}{l}\text { the last abc } \\
\text { ot wanting } \\
\text { he time }\end{array}$ & $\begin{array}{l}\text { ortions, } \\
\text { children }\end{array}$ & $\begin{array}{l}\text { The firs } \\
\text { last was }\end{array}$ & $\begin{array}{l}\text { st was the womar } \\
\text { s hers and her pa }\end{array}$ & $\begin{array}{l}\text { n's, and the } \\
\text { rtner's }\end{array}$ \\
\hline Lorena & Same as in pre & evious pregnancies & & Bein & g HIV+ & & The wo & man's own & \\
\hline Tatiana & Same as in pre & evious pregnancy & & & ther & & The wo & man's own & \\
\hline Lúcia & Same as in pre & evious pregnancies & $\mathrm{Lac}$ & ck of socioecc & onomic con & aditions & The wo & man's own & \\
\hline
\end{tabular}

from high school; one had graduated from college; one had graduated from elementary school, and six had incomplete elementary schooling. As to time of diagnosis, half of the interviewees received their diagnosis of HIV before the age of 21. Moreover, most women (16) already had children at the time of the diagnosis (Chart 1).
In more than half of the women (11/18), time between diagnosis and post-diagnosis abortion (or first abortion) was 2 years or less. This was the case of Ester, aged 29, of mixed race and high school graduate. Ester received the diagnosis at the age of 21, during the pregnancy that terminated in abortion. A similar situation was lived 
Chart 1. continuation

\begin{tabular}{|c|c|c|c|c|c|c|c|c|c|}
\hline Name $^{a}$ & Age & Schooling & & $\begin{array}{c}\text { Number of } \\
\text { marriages }\end{array}$ & $\begin{array}{c}\text { Age at } \\
\text { diagnosis }\end{array}$ & \multicolumn{2}{|c|}{$\begin{array}{c}\text { Number of } \\
\text { children before } \\
\text { diagnosis }\end{array}$} & $\begin{array}{l}\text { Number of } \\
\text { children after } \\
\text { diagnosis }\end{array}$ & $\begin{array}{c}\text { Age } \\
\text { at abortion }\end{array}$ \\
\hline Julia & 35 years-old & \multicolumn{2}{|c|}{ high school graduate } & 4 & 18 & \multicolumn{2}{|l|}{3} & & 31 \\
\hline Ester & 29 years-old & \multicolumn{2}{|c|}{ high school graduate } & 0 & 21 & \multicolumn{2}{|l|}{0} & & 21 \\
\hline Catarina & 33 years-old & \multicolumn{2}{|c|}{ high school graduate } & 0 & 16 & \multicolumn{2}{|l|}{1} & & 18 \\
\hline Daiane & 42 years-old & \multicolumn{2}{|c|}{ high school graduate } & 1 & 28 & \multicolumn{2}{|l|}{1} & & 28 \\
\hline Tainá & 27 years-old & \multicolumn{2}{|c|}{ high school graduate } & 1 & 21 & \multicolumn{2}{|l|}{0} & & 24 \\
\hline Elaine & 38 years-old & \multicolumn{2}{|c|}{ high school graduate } & 2 & 27 & \multicolumn{2}{|l|}{2} & & 28 \\
\hline Mariana & 33 years-old & \multicolumn{2}{|c|}{ high school graduate } & 2 & 18 & \multicolumn{2}{|l|}{1} & & 21 \\
\hline Carolina & 33 years-old & \multicolumn{2}{|c|}{ incomplete elementary school } & 3 & 19 & \multicolumn{2}{|l|}{1} & & 21,25 and 29 \\
\hline Rita & 45 years-old & \multicolumn{2}{|c|}{ incomplete elementary school } & 3 & 35 & \multicolumn{2}{|l|}{1} & & 40 \\
\hline $\mathrm{Name}^{\mathrm{a}}$ & \multicolumn{2}{|c|}{ Partner at the time of abortion } & \multicolumn{4}{|c|}{ Reason for abortion } & \multicolumn{3}{|c|}{ Initiative for abortion } \\
\hline Julia & \multicolumn{2}{|c|}{ Not the same as in previous pregnancy } & \multicolumn{4}{|c|}{ Being HIV+ } & \multicolumn{3}{|c|}{ The woman's and her relatives' } \\
\hline Ester & \multicolumn{2}{|c|}{-} & \multicolumn{4}{|c|}{ Being HIV+ } & \multicolumn{3}{|c|}{ The woman's own } \\
\hline Catarina & \multicolumn{2}{|c|}{ Same as in previous pregnancy } & \multicolumn{4}{|c|}{ Being HIV+ } & \multicolumn{3}{|c|}{ Her partner's } \\
\hline Daiane & \multicolumn{2}{|c|}{ Not the same as in previous pregnancy } & \multicolumn{4}{|c|}{ Being HIV+ } & \multicolumn{3}{|c|}{ The woman's own } \\
\hline Tainá & Not the same & in previous pregnancy & & ot wanting cl & ildren at th & e time & The & woman's and h & ner partner's \\
\hline Elaine & Not the same & in previous pregnancy & & & $\begin{array}{l}\text { g HIV+ } \\
\text { ther }\end{array}$ & & The & woman's own & \\
\hline Mariana & Not the same & in previous pregnancy & & $\begin{array}{l}\text { e reason for } t \\
\text { rtions was th }\end{array}$ & $\begin{array}{l}\text { he first and } \\
\text { e woman } n\end{array}$ & $\begin{array}{l}\text { the last } \\
\text { ot being }\end{array}$ & The & woman's own & \\
\hline Carolina & $\begin{array}{l}\text { Same as in pre } \\
3 \text { abortions }\end{array}$ & ious pregnancies in the & & Bein & g HIV+ & & $\begin{array}{l}\text { The } \\
\text { abo }\end{array}$ & $\begin{array}{l}\text { woman's own } \\
\text { tions }\end{array}$ & in both \\
\hline Rita & Not the same & in previous pregnancy & & & & & The & woman's own & \\
\hline
\end{tabular}

${ }^{\mathrm{a}}$ The names of interviewees have been changed.

by Camila, aged 42, white, incomplete elementary schooling, who received the diagnosis at the age of 31 and got pregnant at the age of 32, of a pregnancy that resulted in abortion.

However, the relation between the HIV diagnosis and abortion does not seem to be so direct. Six of the interviewees had already had at least one abortion before knowing to be HIV positive. One of them had 14 pregnancies terminated by abortion before the diagnosis and had another abortion after the diagnosis. Moreover, as to reproductive trajectory, it should be highlighted that post-diagnosis abortion did not end the reproductive life of many of the interviewees (7/18). In other words, these women carried other pregnancies to term after aborting. One example of this is the case was Catarina, aged 33, white and high school graduate. Catarina found out she was 
living with HIV at the age of 16 , when her son died due to HIV. The pregnancy that ended in an induced post-diagnosis abortion was her second pregnancy and happened when she was 18 years old. At the age of 26, Catarina got pregnant again and carried the pregnancy to term.

More than half of the interviewees (9/17) stated as main reason for abortion to be living with HIV. The following were other reasons: lack of financial means (3/17), the woman and/or her partner not wanting children at that moment $(2 / 17)$, not being married (2/17) and other reasons (2/17). Although in half of the pregnancies the reason for abortion was HIV, only three of nine women who stated this reason did not have other children after receiving the diagnosis. Similarly, of these nine women who declared as reason to abort be living with HIV, four of them had a history of abortion before the diagnosis (Chart 1).

Of the pregnancies for which this information is available, nearly half $(9 / 20)$ were terminated with the use of Misoprostol, four by vacuum aspiration, one by curettage, and six by homemade methods (probes, teas, infusions or plant sponges). In most pregnancies (12/18), the initiative to abort was solely of the woman; in two cases, it was shared with the partner and relatives. Two women who had more than one abortion stated that, in one occasion, the initiative was her own only and that, in the other, the decision was negotiated with the partner or relatives. Only one interviewee reported that the decision to abort was taken by the partner (Chart 1). The case of Carla, aged 33, black, an elementary school graduate, illustrates the situations described herein. Carla found out to be living with HIV at the age of 21 and had a pregnancy terminated by abortion at the age of 23 . The main reason for terminating the pregnancy was to be living with HIV. The initiative to abort was her own, and abortion was done by vacuum aspiration. At the age of 26 , Carla got pregnant again and carried the pregnancy to term.

It is also recurrent in the reproductive trajectory of the women interviewed the fact that their children were from different fathers. Only two women had all their children with the same partner. As to partners, it is noteworthy that, in more than half of the pregnancies, the partner of the pregnancy that terminated by abortion post-diagnosis was different from the partner of the previous pregnancy. Despite this change of partners, in most pregnancies ended by induced abortion post-diagnosis, the women lived with their partners, what may indicate a certain stability in the relationship. This was the case of Aura, aged 36, white and high school graduate. Aura had two marriages and, in the past year, two partners. She had six pregnancies. The first pregnancy, which was terminated by a spontaneous abortion, was with her first partner, with whom Aura lived. The second pregnancy, also terminated by a spontaneous abortion, was with another partner, with whom Aura did not live. The third, the fourth and the fifth pregnancies were with the same partner, that is, the partner of her first marriage, who she had remarried. While the third and the fifth pregnancies were terminated by induced abortions, the fourth pregnancy resulted in a live-born child. Finally, Aura's sixth pregnancy, terminated by an induced abortion, was with her present partner, with whom Aura did not live.

As to the prevention of DST/Aids and pregnancies, when the first and last sexual intercourses were considered, it was found that most interviewees did not make a consistent use of a contraceptive method, neither the use of a condom. It is noteworthy that one of the interviewees who stated having terminated a pregnancy because she did not want children at that moment did not make use of any contraceptive methods.

Violence was a common finding in the life story of the women who aborted after the diagnosis. More than half $(14 / 18)$ of the interviewees suffered some type of violence (psychological, physical, or sexual). Also, more than half of them (11/18) stated having made use of some type of drug during life.

\section{Discussion}

The HIV diagnosis has an undeniable impact on the reproductive decisions of WLHA. However, its influence on the decision to terminate a pregnancy should be viewed situationally, since most women who stated not wanting the pregnancy because they were living with the virus had other children after having received the diagnosis. In this sense, Villela et al. ${ }^{3}$ show that, even in the cases where HIV interfered in the decision to abort, this reason was associated to other factors. These other factors, in the case of the WLHA, are reinforced by the concrete possibility of becoming ill or having an early death ${ }^{3,13,14}$.

Thus, the analysis of the reproductive trajectory of the women who aborted after receiving the diagnosis indicates that the decision to interrupt a pregnancy is associated to a set of factors, not exclusively to HIV. Therefore, an unplanned 
pregnancy has different meanings depending on where in her life cycle the woman is, and the decision to terminate pregnancy may not be understood outside the context of the life trajectory of women $^{17}$.

The present findings indicate that, at first, right after the diagnosis is received, HIV is an important factor in the decision to end a pregnancy. This becomes evident when one notes that, in most cases, there is a time interval of up to two years between diagnosis and abortion. Thus, besides having to deal with a relatively recent diagnosis, which brings along all the implications of finding one's self HIV-positive, such as the stigma and the need of follow-up and treatment, a pregnancy occurred soon after the diagnosis, or a diagnosis given during pregnancy, require women to make a decision about its continuation or termination, making that moment in life even more delicate ${ }^{18,19}$.

However, it seems this relation between HIV and abortion changes in time and HIV is no longer a determining reason for abortion. A result of this is that many of the women who stated HIV as the main reason for abortion had other pregnancies post-diagnosis. This finding may indicate that the more time post-diagnosis the more knowledge WLHA have about the PMTCT and the possibility of giving birth to children free of the virus, as shown by the results published by Bui et al. ${ }^{13}$.

Moreover, other factors, such as lack of socioeconomic conditions and the desire not to have more children may play a role in the post-diagnosis period. Thus, as to the lack of socioeconomic conditions, studies conducted in Vietnam ${ }^{9,13}$ and in South Africa ${ }^{20}$ reinforce our finding that not having the financial means to raise a child was a recurring reason for abortion.

The desire not to have children, or not to have children at that particular moment, was also a reason for abortion stated by WLHA. However, there seems to be an inconsistency between the lack of desire to become a mother and the use of contraception. One of the women who stated having terminated a pregnancy for not wanting to have children in that moment was not making use of contraception when she got pregnant. In this same sense, one interviewee had 15 pre-diagnosis abortions, what may indicate that women may also be using abortion as a contraceptive method. While quantitative studies did not find an association between the use of contraception and abortion in WLHA ${ }^{21,22}$, a qualitative study conducted in Brazil showed that the inconsis- tent use of oral contraceptives and condoms was common in the population studied ${ }^{23}$.

In this context, another factor that may strongly influence the decision to keep or terminate a pregnancy is the relationship with the partner. In the present study, a myriad of situations regarding this determining factor was identified. For instance, there were accounts of abortion in situations where the woman was living with the partner who was the same of the previous pregnancy (what shows some relationship stability). On the other hand, there were also abortions in situations of eventual relationships. Thus, subjective issues may interfere in this relation between being in a relationship with a partner and maintaining pregnancy, as well as having a partner willing to assume paternal responsibilities and sharing the responsibility for raising children $^{3}$ or still the evaluation as to the longevity and quality of the marital relationship ${ }^{17}$. In this sense, in their study of Swedish women, with and without abortion experience, Tornbom et al. ${ }^{24}$ showed that not only the presence of a partner influences the decision to maintain or terminate a pregnancy but also the stability and safety that the woman finds in her relationship with the partner. In other words, the more stable the relationship, the greater is the weight of the partner's opinion on the decision about the pregnancy outcome ${ }^{24,25}$. Moreover, Zabin et al. ${ }^{26}$ suggest that changing partners in-between the different pregnancies makes women change their opinion about the desire to be pregnant. In the present findings, in nearly half of the pregnancies that ended in abortion, partners were different from those of the immediately previous pregnancy.

In this context, although many times the decision to maintain or not a pregnancy is taken depending on the availability of the partner to take responsibility for parenthood, this decision is not always taken together with the partner.

Women's prominence in the decision to end a pregnancy is evident because in most pregnancies the initiative to terminate pregnancy was taken by the woman (who either made the decision alone or together with her partner and/ or relatives). This reinforces the idea showed by qualitative studies conducted in two provinces in Vietnam ${ }^{13}$ and in South Africa ${ }^{11}$ that, if a woman has made up her mind to terminate pregnancy, she does not communicate her decision to her partner, foreseeing resistance on his part, opting, therefore, to seek health services on her own.

Other conditions that may place women in a situation of greater vulnerability were report- 
ed by interviewees. Most interviewees reported having suffered some type of violence in their life (psychological, physical, or sexual). A quantitative study conducted in the United States showed an association between sexual violence and induced abortion ${ }^{27}$. Similarly, a qualitative study conducted in Brazil showed that the occurrence of non-consensual sex as well as physical and sexual violence were relatively common in the life story of women who had abortions throughout life ${ }^{23}$.

The use of illicit drugs adds to this context of vulnerability. Half of the interviewees stated the use of illicit drugs. In line with the findings of the present study, Barbosa et al. ${ }^{21}$ showed that having used illicit drugs some time in life was associated to a higher risk of voluntary end of pregnancy. This finding is reinforced by the study by Kline et al. ${ }^{22}$ which pointed to a higher risk of this outcome in women with a history of crack cocaine use.

In conclusion, the analysis of the reproductive trajectory of women living with HIV/Aids shows that there is no specific profile of the woman who aborts after receiving the HIV diagnosis but that some characteristics (change of partners, history of violence and drug use) may indicate a greater vulnerability of some women. Although the HIV diagnosis may play a role in the decision to end a pregnancy, it does not necessarily result in the end of the woman's reproductive trajecto- ry. Thus, abortions should be understood within a diversity of decision-making processes that refer to specific moments in the life cycle, forms of organization of family and marriage, as well as the socioeconomic context in which pregnancy takes place ${ }^{17}$. A change in one of the elements of this situation may result in a different decision, and that is why a pregnancy may be interrupted due to the HIV diagnosis at a given moment and, later, another pregnancy may be taken to term, despite HIV.

In comparison to WNLHA, the higher rates of abortion in WLHA pointed by international and national literature ${ }^{7-12,22,27,28}$ suggest that the access the latter population is having to information and efficient contraceptive methods is poor, despite the heavy investment health policies and services have made towards the use of condom ${ }^{29}$. Thus, investing in the promotion and provision of inputs for double protection is a fundamental action in order to decrease the number of unplanned pregnancies. Still, the development of continuous educative actions aiming to prevent unwanted pregnancies and STD, especially along with the most vulnerable populations, is important. Therefore, the assurance of the reproductive rights of WLHA involves not only the decrease of mother-to-child transmission of HIV but also the assurance of access to an early diagnosis, educative actions, reproductive planning, efficient contraceptive methods, as well as prevention inputs. 


\section{Collaborations}

FB Pilecco and DR Knauth participated in the study concept and design, data analysis and interpretation, as well as the writing of this paper; LB Teixeira and A Vigo participated in the study concept and design, the critical review of the paper, and the approval of its final version.

\section{References}

1. Connor EM, Sperling RS, Gelber R, Kiselev P, Scott G, O'Sullivan MJ, VanDyke R, Bey M, Shearer W, Jacobson RL. Reduction of maternal-infant transmission of human immunodeficiency virus type 1 with zidovudine treatment. Pediatric AIDS Clinical Trials Group Protocol 076 Study Group. N Engl J Med 1994; 331(18):11731180.

2. UNAIDS/ONUSIDA. Chegando a Zero: Estratégia do UNAIDS/ONUSIDA 2011-2015. Brasília: Programa Conjunto das Nações Unidas sobre HIV/VIH/Aids/SIDA (UNAIDS/ONUSIDA); 2010

3. Villela WV, Barbosa RM, Portella AP, Oliveira LA. Motives and circumstances surrounding induced abortion among women living with HIV in Brazil. Cien Saude Colet 2012; 17(7):1709-1719.

4. Fisch P. Diagnóstico de HIV/Aids e o Uso de Antirretrovirais em Mulheres Usuárias dos serviços especializados em HIV/Aids de Porto Alegre [dissertação]. Porto Alegre: Universidade Federal do Rio Grande do Sul; 2013.

5. Gruskin S, Firestone R, Maccarthy S, Ferguson L. HIV and pregnancy intentions: do services adequately respond to women's needs? Am J Public Health 2008; 98(10):1746-1750.

6. Pilecco FB. Aborto Provocado em Mulheres Vivendo com HIV/Aids [tese]. Porto Alegre: Universidade Federal do Rio Grande do Sul; 2014.

7. van Benthem BH, de Vincenzi I, Delmas MC, Larsen C, van den Hoek A, Prins M. Pregnancies before and after HIV diagnosis in a european cohort of HIV-infected women. European Study on the Natural History of HIV Infection in Women. Aids 2000; 14(14):21712178.

8. Bongain A, Berrebi A, Marine-Barjoan E, Dunais B, Thene M, Pradier C, Gillet JY. Changing trends in pregnancy outcome among HIV-infected women between 1985 and 1997 in two southern French university hospitals. Eur J Obstet Gynecol Reprod Biol 2002; 104(2):124-128.

9. Bui KC, Gammeltoft T, Nguyen TT, Rasch V. Induced abortion among HIV-positive women in Quang Ninh and Hai Phong, Vietnam. Trop Med Int Health 2010; 15(10):1172-1178

10. Hankins C, Tran T, Lapointe N. Sexual behavior and pregnancy outcome in HIV-infected women. Canadian Women's HIV Study Group. J Acquir Immune Defic Syndr Human Retrovirol 1998; 18(5):479-487.

11. Barbosa RM, Pinho AA, Santos NS, Filipe E, Villela W, Aidar T. Induced abortion in women of reproductive age living with and without HIV/Aids in Brazil. Cien Saude Colet 2009; 14(4):1085-1099.

12. Thackway SV, Furner V, Mijch A, Cooper DA, Holland D, Martinez P, Shaw D, van Beek I, Wright E, Clezy K, Kaldor JM. Fertility and reproductive choice in women with HIV-1 infection. Aids 1997; 11(5):663-667.

13. Bui KC, Hanh NT, Rasch V, Gammeltoft T. Induced abortion among HIV-positive women in Northern Vietnam: exploring reproductive dilemmas. Cult Health Sex 2010; 12(Supl. 1):S41-54.

14. Orner P, Bruyn M, Harries J, Cooper D. A qualitative exploration of HIV-positive pregnant women's decision-making regarding abortion in Cape Town, South Africa. SAHARA J 2010; 7(2):44-51. 
15. Floridia M, Tamburrini E, Tibaldi C, Anzidei G, Muggiasca ML, Meloni A, Guerra B, Maccabruni A, Molinari A, Spinillo A, Dalzero S, Ravizza M; Italian Group on Surveillance on Antiretroviral Treatment in Pregnancy. Voluntary pregnancy termination among women with HIV in the HAART era (2002-2008): a case series from a national study. AIDS Care 2010; 22(1):50-53.

16. Brasil. Ministério da Saúde (MS). Conselho Nacional de Saúde. Resolução no 196 de 10 de outubro de 1996. Diretrizes e Normas Regulamentadoras de Pesquisas Envolvendo Seres Humanos. Diário Oficial da União 1996; 16 out.

17. Donati P, Cèbe D, Bajos N. Interrompre ou poursuivre la grossesse? Construction de la décision. In: Bajos N, Ferrand M, Equipe GINÉ, editors. De la contraception à l'avortement: sociologie des grossesses non prévues. Paris: INSERM; 2002.

18. Guimarães CD. Aids no Feminino: Por que a cada dia mais mulheres contraem Aids no Brasil? Rio de Janeiro: UFRJ; 2001.

19. Guilhem D. Escravas do risco: bioética, mulheres e Aids. Brasília: Editora da Universidade de Brasília; 2005.

20. Orner P, de Bruyn M, Harries J, Cooper D. A qualitative exploration of HIV-positive pregnant women's decision-making regarding abortion in Cape Town, South Africa. SAHARA J 2010; 7(2):44-51.

21. Barbosa RM, Pinho A, Santos NS, Filipe E, Villela W, Aidar T. Induced abortion in women of reproductive age living with and without HIV/Aids in Brazil. Cien Saude Colet 2009; 14(4):1085-1099.

22. Kline A, Strickler J, Kempf J. Factors associated with pregnancy and pregnancy resolution in HIV seropositive women. Soc Sci Med 1995; 40(11):1539-1547.

23. Barbosa RM, Pinho AA, Santos NS, Villela WV. Exploring the relationship between induced abortion and HIV infection in Brazil. Reprod Health Matters 2012; 20(Supl. 39):80-89.
24. Tornbom M, Ingelhammar E, Lilja H, Svanberg B, Moller A. Decision-making about unwanted pregnancy. Acta Obstet Gynecol Scand 1999; 78(7):636-641.

25. Santelli JS, Speizer IS, Avery A, Kendall C. An exploration of the dimensions of pregnancy intentions among women choosing to terminate pregnancy or to initiate prenatal care in New Orleans, Louisiana. Am J Public Health 2006; 96(11):2009-2015.

26. Zabin LS, Huggins GR, Emerson MR, Cullins VE. Partner effects on a woman's intention to conceive: 'not with this partner'. Fam Plann Perspect 2000; 32(1):3945.

27. Bedimo AL, Bessinger R, Kissinger P. Reproductive choices among HIV-positive women. Soc Sci Med 1998; 46(2):171-179.

28. Sherr L, Barnes J, Elford J, Olaitan A, Miller R, Johnson M. Women with HIV disease attending a London clinic. Genitourin Med 1997; 73(4):274-279.

29. Teixeira LB. Saúde Sexual e Reprodutiva de Mulheres Vivendo com HIV/Aids no Sul do Brasil [tese]. Porto Alegre: Universidade Federal do Rio Grande do Sul; 2012.

Article submitted 09/01/2014

Approved 10/07/2014

Final version submitted 10/09/2014 